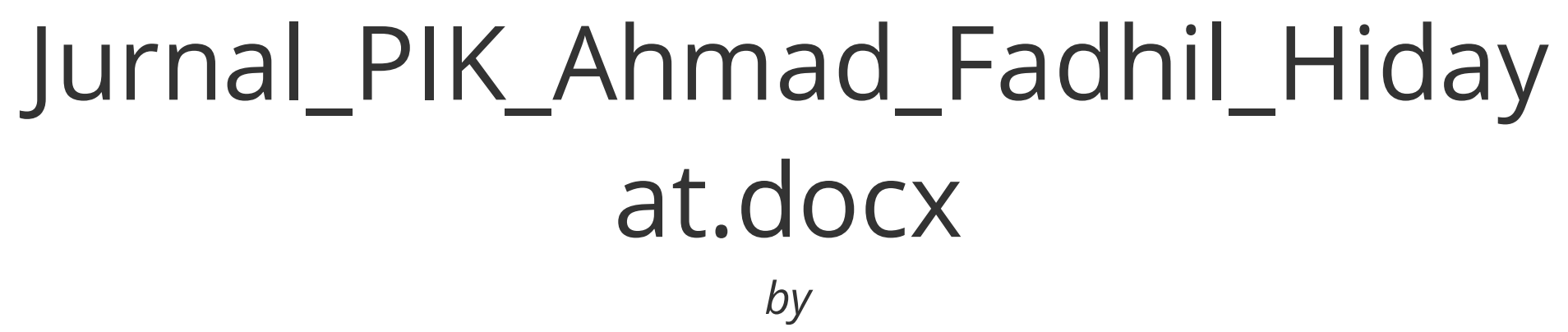

Submission date: 01-Jan-2022 10:36PM (UTC+0700)

Submission ID: 1736760185

File name: Jurnal_PIK_Ahmad_Fadhil_Hidayat.docx (85.62K)

Word count: 3141

Character count: 20403 


\title{
PERANAN PERANGKAT LUNAK KOMPUTER DALAM SISTEM INFORMASI MANAJEMEN
}

\author{
Ahmad Fadhil Hidayat ( 0702212222 ) \\ SISTEM INFORMASI - 6 FST UIN
}

Sumatera Utara Medan 2021/2022

af871310@gmail.com

\begin{abstract}
ABSTRAK
Pemrograman PC adalah salah satu perangkat yang diharapkan untuk menjalankan PC. Pemrograman adalah gadget yang tidak boleh terlihat dan dihubungi secara langsung, namun harus dimungkinkan oleh klien. PC (pemrograman) adalah bermacam-macam informasi elektronik yang dikumpulkan dan dipesan oleh PC, informasi elektronik yang disimpan oleh PC dapat terdiri dari proyek atau perintah yang akan menjalankan perintah. Pemrograman juga disebut sebagai penerjemah perintah yang dijalankan oleh klien PC untuk dikirim atau ditangani oleh peralatan. Melalui produk atau pemrograman ini, PC dapat menjalankan tuntutan. Sebagai aturan $\underset{2}{2}$, atau pemrograman dapat dikelompokkan menjadi tiga bagian, untuk lebih spesifik, pemrograman kerangka kerja, pemrograman kerangka aplikasi dan dialek pemrograman.
\end{abstract}

Kata Kunci : Perangkat Lunak/Software dan pemrograman 


\section{A. PENDAHULUAN}

Di zaman yang serba canggih ini, perkembangan dan kemajuan inovasi informasi dan surat menyurat semakin pesat. Kami dapat mengambil bagian dalam kenyamanan mendapatkan data dari berbagai penjuru dunia dalam satu atau dua saat. Secara konsisten PC mengalami kemajuan dalam dua model, rencana dan kerangka kerja. Jika dulu orang hanya menggunakan PC di tempat kerja dan di rumah, saat ini orang bisa menggunakan PC di mana saja.

PC tidak akan diisolasi dari pemrograman. Kemajuan pesat inovasi pemrograman pada PC mendorong orang untuk memiliki opsi untuk memanfaatkan kompleksitas mekanis dalam berbagai tujuan. Dalam dunia bisnis, inovasi pemrograman digunakan untuk penanganan informasi yang mencakup penanganan kata, penimbunan informasi, ${ }_{14}$ dan penanganan informasi kantor. Selain sebagai pengolah kata dan angka, pemrograman telah merambah hampir semua bidang. Mulai dari mainan anakanak, kamera canggih, ponsel, kantor hiburan dan perangkat rumah tangga.
Pemrograman itu sendiri ketika diterjemahkan ke dalam bahasa Indonesia dicirikan sehagai pemrograman. Pemrograman berarti perangkat yang tidak berbentuk asli, tetapi dapat digunakan oleh klien atau kliennya. Karena disebut pemrograman, kecenderungannya juga unik dalam kaitannya dengan peralatan. Dengan asumsi peralatan adalah gadget asli karena di dalamnya sangat mungkin terlihat jelas oleh mata dan dipegang secara langsung, maka pada saat itu, produk tersebut tidak dapat dihubungi dan dilihat secara nyata, namun dapat dikerjakan oleh klien.

Pemrograman adalah program PC yang menggunakan informasi untuk memasukkan semua latihan PC. misalnya, menyimpan informasi, memeriksa informasi, mengendalikan informasi dan memperoleh hasil dari informasi yang dilakukan oleh peralatan.

Pemrograman adalah sekumpulan informasi elektronik yang akan dikendalikan oleh PC, informasi elektronik yang disimpan oleh PC dapat berupa proyek atau pedoman yang akan menjalankan suatu permintaan. Pemrograman disebut juga 


penerjemah perintah yang
2 dikendalikan oleh klien PC untuk
dikirim atau ditangani oleh peralatan.
Melalui produk atau pemrograman ini,
PC dapat menjalankan perintah.

\section{B. TINJAUAN PUSTAKA}

Software adalah program perintah pada PC, yang bila diberikan permintaan oleh klien akan memberikan kapasitas dan eksekusi yang benar untuk dibentuk oleh klien. Pernyataan ini menggambarkan bahwa produk atau program ini mampu memberikan permintaan ke PC, sehingga kapasitas PC idealnya sesuai dengan keinginan klien atau klien yang menyediakan permintaan tersebut. [2]

Pemrograman adalah perangkat yang berfungsi sebagai pengontrol latihan kerja PC dan segala arah yang mengarah ke kerangka PC. Kemudian, ditegaskan pula bahwa produk tersebut merupakan perangkat yang mencakup kolaborasi klien dengan PC yang menggunakan bahasa mesin.[3]

Software sebagai sebuah sistem program yang sudah diatur dan juga disusun sedemikian rupa, ditujukan untuk memberikan perintah ke dalam komputer atau hardware dalam rangka menyelesaikan sebuah tugas, pekerjaan, dan juga tuntutan tertentu, yang membantu menghubungkan user sebagai brainware dengan kompter sebagai hardwarenya. Software berfungsi sebagai pelengkap dari tiga komponen atau elemen penting pada sebuah sistem komputer. Secara teknis, tidak semuauser atau brainware memiliki kemampuan yang baik dalam mendefinisikan sebuah bahasa mesin. Karena itulah, dengan adanya software, perangkat ini akan sangat baik dan sangat membantu kebutuhan setiap usernya dalam melakukan sesuatu dan menyelesaikan tugas-tugas tertentu dengan menggunakan komputer.

Secara garis besar software atau perangkat lunak dapat diklasifikasikan menjadi tiga bagian yaitu, perangkat lunak sistem operasi, sistem operasi, sistem aplikasi dan bahasa program. Sistem Operasi merupakan pengelola seluruh sumber daya yang terdapat pada sistem komputer dan sebagai extended machine yang menyediakan layanan pada pengguna. Menyamankan dan memudahkan penggunaan serta pemanfaatan sumber daya sistem komputer. [1] 
Sistem Aplikasi merupakan suatu intruksi atau pernyataan yang ada di suatu perangkat keras atau Hardware baik itu komputer atau smartphone yang di rancang sedemikian rupa agar bisa mengolah suatu masukan (input) menjadi keluaran (output). Sistem aplikasi dirancang untuk mengolah data dengan aturan serta ketentuan tertentu dan menggunakan bahasa pemograman tertentu.[6]

Bahasa pemograman adalah suatu cara atau teknik berkomunikasi atau interaksi antara manusia sebagai makhluk hidup dengan mesin yang dalam hal ini adalah komputer sebagai suatu perangkat peralatan.

Bahasa pemograman berisi kumpulan perintah atau instruksi yang diketikkan oleh manusia menggunakan perantaraan suatu perangkat keras berupa papan ketik (keyboard).

Bahasa pemograman juga akan menentukan bagaimana data akan disimpan, dikirim dan mendapatkan kembali data tersebut serta apa yang akan dilakukan selanjutnya jika terdapat kondisi yang beragam seperti misalnya dalam memberikan instruksi prioritas terhadap peralatan I/O (input/output), multimedia dan lainlain.

Objek di dalam software

Analisis \& desain adalah sesuatu

yang berupa konsep konsep

(concept) dan benda (thing) sesuatu

yang mengadakan dengan

lingkungan. Objek ini biasanya

adalah kata benda namun alam

konteks OOP objek ini bukan saja

di lihat atau di raba, objek

merupakan sesuatu yang abstrak di

dalam sistem tersebut seperti file,

table, database, event, sistem

messages [5]

\section{C.METODOLOGI}

Peralatan dan bahan penelitian yang digunakan dalam penelitian ini merupakan kunjungan ke suatu halaman world wide web (site visit). Melalui beberapa link sebagai berikut :

https://dosenit.com/ilmu-

komputer/komputerdasar/pengertiansoftware

19 https://luftwaffed.wordpress.com/2017 
/11/04/ makalah-pengenalan-softwareopratingsystem-application-software/

http://ptiasugeng.blogspot.com/2015/0

$\underline{1 / j u r n a l ~-~ p e r a n g k a t-l u n a k-s o f t w a r e-~}$

$\underline{\text { bab-i.html? } \mathrm{m}=1}$

Selain link di atas, pedoman tambahan dalam penelitian ini adalah Buku "Dasar-Dasar Komputer" yang ditulis oleh Bapak Yahfizham. lalu setelah mengunjungi situssitus tersebut dapat disimpulkan pula bahwa Komponen Perangkat Lunak terdiri dari Sistem operasi, sistem aplikasi dan bahasa pemograman.

Dalam metode pemilihan sumber artikel dan komposisi, dilakukan pemisahan subjek yang akan penulis teliti, khususnya pemrograman PC. Setelah mempelajari dan memahami isi bacaan dari setiap artikel terkait, penulis esai membuat saluran aplikasi. Setelah dipisahkan maka penulis membuat standar untuk setiap judul artikel dimana terdapat kata pemrograman, kerangka kerja, aplikasi dan pemrograman. Penulis mendapatkan tiga artikel yang dapat dijadikan referensi dalam survei ini.

\section{HASIL DAN PEMBAHASAN}

Sebuah PC tanpa (pemrograman) tidak dapat bekerja seperti yang diharapkan. PC (pemrograman) adalah sekumpulan informasi elektronik yang disimpan dan diawasi oleh PC. Informasi elektronik yang disimpan oleh PC dapat berupa proyek atau arahan yang akan mengeksekusi suatu perintah.

\begin{tabular}{l}
\multicolumn{2}{c}{ Pemrograman disebut juga } \\
penerjemah perintah \\
dikendalikan oleh klien PC untuk \\
dikirim atau ditangani oleh peralatan.
\end{tabular}

Pemrograman memiliki bagianbagian yang bekerja sama untuk membingkai unit soliter dalam melakukan kapasitasnya. Bagianbagian ini dipartisi menjadi tiga kelompok, untuk lebih spesifik, Kerangka Kerja, Kerangka Aplikasi dan Dialek Pemrograman.

\section{SISTEM OPERASI}

Pada dasarnya kerangka kerja adalah program PC yang berisi (perintah) yang bertanggung jawab untuk menyelesaikan kerjasama antara 
manusia dan PC, sehingga PC dapat mengisi sesuai keinginan. kerangka aplikasi dan bahasa pemrograman. Kerangka kerja adalah pengawas dari banyak relatif aset yang terkandung dalam kerangka kerja PC dan sebagai mesin panjang yang menawarkan jenis bantuan kepada klien. Kenyamanan dan kemudahan serta penggunaan aset kerangka kerja PC.

Terdapat dua jenis sistem operasi berdasarkan tampilan antarmuka kepada penggunanya (user interface) yaitu yang berbasis CUI (Character User Interface) dan berbasis GUI (Graphical User Interface). Sistem operasi berbasis CUI, misalnya : DOS (Disk Operating Sistem) dan Sistem Operasi UNIX dan Linux pada mode terminal atau konsol.

Sedangkan sistem operasi berbasis GUI, misalnya : Microsoft Windows 9x, 2000, NT, XP, serta sistem operasi UNIX dan Linux yang telah mendukung GUI.

Jenis jenis Sistem operasi :
1) DOS (Disk Operating Sistem)

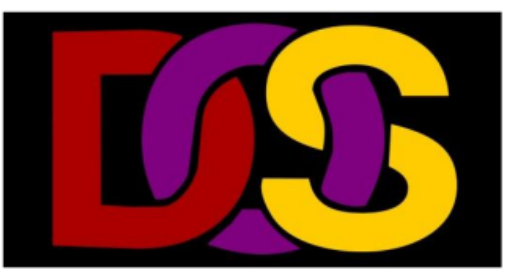

DOS (Disk Operating Sistem) adalah sistem kerja yang digunakan untuk menangani semua aset di PC. Saat menjalankan DOS, klien harus memberikan perintah menggunakan konsol PC.

Perintah yang diberikan akan ditafsirkan oleh kerangka DOS seperti yang ditunjukkan oleh kapasitas pesanan. Perintah yang ada di DOS misalnya, misalnya nama record program yang memiliki augmentasi atau diakhiri dengan .bat, .exe, dan lain-lain. Selain menyusun nama-nama dokumen dari program pesanan, DOS juga biasanya digabungkan dengan batas-batas yang berbeda di mana batas tersebut kemudian disusun nama catatan program.

DOS (Disk Operating Sistem) untuk mengontrol atau mengatur latihan PC, mengontrol informasi dan menghasilkan proses informasi pada PC, mengawasi memori PC dan untuk merekam dan membuat katalog para 
eksekutif. Kelebihan dari kerangka kerja DOS adalah, ringan sehingga tidak memakan banyak memori, ukuran kecil dan kemiripan yang tinggi. Sedangkan kelemahannya adalah tidak ada titik interaksi dan arahannya hanya melalui komposisi, tidak ada desain.

\section{2) Sistem Operasi UNIX}

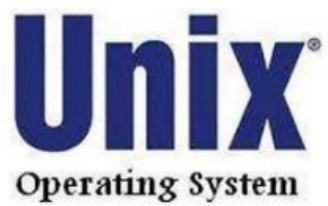

Unix atau UNIX adalah kerangka kerja (sistem operasi) yang dibuat pada tahun 1965 melalui proyek sebelumnya yang disebut Multiplexed Data and Processing Administration atau disingkat Multics dengan harapan bahwa UNIX akan berubah menjadi kerangka kerja yang dapat melakukan banyak tugas, nyaman dan dapat digunakan oleh lebih dari satu klien (multiuser). . Usaha ini sepenuhnya dibiayai oleh US Branch of Safeguard (DARPA).

UNIX menikmati manfaat menjadi kerangka kerja yang praktis gratis, memiliki opsi untuk menjalankan berbagai tugas secara bersamaan (Melakukan banyak tugas), Berbagai kerangka catatan berjenjang,
Kenyamanan, dapat digunakan oleh banyak klien dengan segera (Multiuser) dan memiliki eksekusi yang lebih disukai daripada Windows NT. Sementara kendala UNIX sulit digunakan untuk klien konvensional, tampilannya kurang menarik dan membutuhkan memori yang cukup besar.

\section{3) Sistem Operasi Windows}

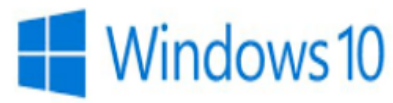

$$
\text { Windows adalah Kerangka }
$$
Kerja yang dibuat oleh Microsoft Organization yang memanfaatkan titik interaksi yang bergantung pada GUI (Graphical UI) atau UI grafis. Dengan Windows, klien tidak perlu mengetik pesanan melalui baris pesanan seperti di MS-DOS. Hanya dengan memanfaatkan mouse atau konsol, klien dapat memberikan perintah untuk membuka menu, bertukar kotak, menjalankan aplikasi, menghapus catatan, dll. Kapasitas kerangka kerja

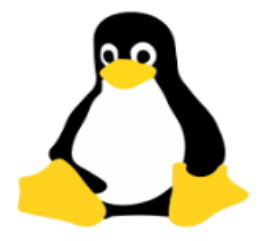


Windows untuk antarmuka aplikasi dan peralatan sehingga mereka dapat dikoordinasikan dalam bekerja dengan andal dan mantap. Windows juga mengontrol dan mengawasi aset yang berjalan, mengingat pemrograman dan peralatan untuk PC dan mengawasi informasi dan informasi hasil dan mengontrolnya. Keuntungan dari Windows adalah dilengkapi dengan antarmuka yang Mudah digunakan dan lebih sederhana selama pembuatan. Kelemahan Windows adalah bahwa itu bukan open source, berbayar dan sangat mahal, mudah diretas karena kerangka keamanannya masih lemah dan tidak berdaya melawan serangan infeksi.

\section{4) Sistem Operasi Linux}

Linux adalah kerangka kerja sumber terbuka. Kerangka kerja Linux lebih baik disebut secara keseluruhan sebagai sirkulasi Linux atau distro linux.
open
gratis, $M a C^{\prime \prime} O S$ tidak ada biaya perizinan dan peningkatannya sangat cepat karena dibuat oleh banyak orang. Meskipun bebannya adalah tidak dapat digunakan oleh klien biasa, aplikasi Linux dibatasi dan cara memperkenalkan Linux benar-benar merepotkan.

\section{5) Sistem Operasi Mac}

Sistem operasi Macintosh atau pemotongan kerangka kerja Mac adalah kerangka kerja selektif yang hanya dapat diakses di PC Macintosh. Kelebihan MarCO lebih stabil, titik interaksinya masuk akal untuk kebutuhan media campuran, memiliki keamanan tinggi dan tidak mudah diretas dan dilindungi dari infeksi. Sementara sisi negatifnya adalah biayanya agak mahal, tidak terlalu ideal untuk bermain game dan bukan open source. 


\section{SISTEM APLIKASI}

Aplikasi adalah pengaturan arah yang luar biasa di PC bagi kita untuk menyelesaikan tanggung jawab tertentu. Kerangka kerja aplikasi tidak dapat tinggal sendiri, menyiratkan bahwa kerangka kerja aplikasi bergantung pada kerangka kerja. Kerangka kerja aplikasi adalah program (sekelompok arahan) yang dibuat atau dimaksudkan untuk alasan tertentu atau spesifik, yang menyiratkan bahwa kerangka kerja aplikasi dibuat sesuai dengan area masalah. Aplikasi kerangka kerja adalah program yang disiapkan untuk digunakan, dibuat untuk melakukan pesanan klien. Aplikasi adalah pemrograman yang dibuat untuk membantu pekerjaan manusia. Selain dapat membantu dan mempercepat jalannya pekerjaan manusia, aplikasi ini juga dapat memberikan hasil yang lebih tepat dalam menangani masalah.

Program aplikasi adalah program komputer yang ditulis dalam suatu bahasa pemrograman dan dipergunakan untuk menyelesaikan masalah tertentu dan melakukan pekerjaan-pekerjaan sesuai kebutuhan yang menggunakan. Dibawah ini adalah berbagai jenis program aplikasi sistem komputer :

\section{Aplikasi Desktop}

Saat ini, banyak aplikasi area kerja yang dapat diakses dan dapat diurutkan ke dalam beberapa klasifikasi. Sebagian dari aplikasi area kerja ini memiliki banyak elemen (seperti Microsoft Word), dan yang lainnya hanya memiliki beberapa elemen (seperti aplikasi jam atau jadwal).

\section{Aplikasi Grafis}

Aplikasi grafis adalah program yang memiliki opsi untuk menangani informasi dalam desain gambar baik dengan membuat gambar baru atau dengan mengubah gambar yang baru dibuat.

\section{Aplikasi Web Browser}

Aplikasi Internet Browser adalah bagian penting dari web, khususnya sebagai area lokal jaringan PC yang menyediakan administrasi http. Oleh karena itu, arti khusus dari internet adalah semua aset dan semua klien di web yang menggunakan HTTP (Hypertext Move Convention). 
10

Aplikasi Multimedia

Aplikasi multimedia merupakan salah satu media hiburan yang dapat kita manfaatkan. Untuk memperhatikan musik MP3 atau menonton film yang sudah kita download, maka pada saat itu kita bisa/bisa memanfaatkan aplikasi ini untuk mengapresiasinya. Windows Media Player dan iTunes adalah aplikasi pemutar media yang terkenal saat ini.

\section{Aplikasi Communication}

Aplikasi komunikasi adalah aplikasi yang paling umum digunakan dan paling terkenal. Aplikasi ini digunakan agar orang dapat berbicara dengan klien PC, ponsel, atau perangkat lain. Model menyerupai aplikasi korespondensi ini antara lain Line, Whatsapp, BBM dan lain sebagainya

\section{Aplikasi DBMS}

Aplikasi DBMS (Databes The board Framework) ini digunakan atau digunakan untuk menyimpan informasi, mengolah informasi dan membuat hasil sebagai data. Ada aplikasi seperti ini yang dapat diakses secara gratis, namun ada juga yang berbayar. Modelnya menyerupai MySQL, Microsoft Access, Prophet, Foxpro dan lain-lain.

\section{BAHASA PEMOGRAMAN}

Bahasa Pemrograman adalah suatu cara atau prosedur untuk menanamkan atau mengasosiasikan antara manusia sebagai makhluk hidup dan mesin, yang dalam hal ini PC sebagai gadget. Sebuah bahasa pemrograman berisi bermacam-macam perintah atau arahan yang disusun oleh orang-orang yang melibatkan peralatan gadget sebagai konsol. Bahasa pemrograman juga akan memutuskan bagaimana informasi akan dikirim dan dipulihkan dan apa yang harus dilakukan segera jika ada kondisi yang berbeda seperti kebutuhan panduan untuk perangkat keras I/O (input/hasil), media, dan lainnya.

Penyusunan arah harus dipahami oleh PC, sehingga bahasa yang disusun memiliki pengelompokan langkah yang wajar, sah, disengaja, aturan luar biasa (tertentu), desain tertentu dan memiliki komponen tertentu (tanda 
baca). Rencana yang mendasari bahasa pemrograman ini dibawa ke dunia dari bahasa biasa yang biasanya digunakan oleh orang-orang dalam berkolaborasi dan berbicara dengan orang yang berbeda.

Dialek pemrograman memberikan persyaratan bagi pengembang untuk memiliki opsi untuk secara eksplisit menyatakan atau memberikan pedoman untuk apa yang akan dilakukan PC. PC hanya memahami satu bahasa, untuk menjadi bahasa mesin tertentu, bahasa mesin terdiri dari kualitas 0 dan 1 yang disebut lanjutan.

Dalam menguraikan dialek pemrograman yang ditulis orang, dibutuhkan metode unik yang disebut compiler dan mediator. Compiler adalah unit unik dalam setiap bahasa pemrograman yang membuat interpretasi kode yang disusun menjadi nilai 0 dan 1 .

Penerjemah adalah metode dalam menyelidiki dan mengeksekusi baris demi baris sekelompok pedoman yang diberikan atau disusun oleh pengembang dalam bahasa pemrograman tertentu.
Bahasa pemrograman asli. Bahasa semacam ini sangat sulit untuk dipahami karena petunjuknya dalam bahasa mesin. Demikian juga disebut konstruksi komputasi tingkat rendah adalah bahasa dengan perencanaan arah PC secara individual. Setiap panduan pengumpulan diuraikan menggunakan agen pembangun. Dialek pemrograman tingkat menengah telah beralih ke bahasa biasa, meskipun faktanya masih sangat sulit untuk dipahami karena mereka menggunakan kependekan seperti STO yang berarti simpan (STORE) dan MOV yang berarti (MOVE). Yang diingat untuk bahasa ini adalah Constructing agent, Fortran dan lainlain.

\section{Algoritma (Algorithm)}

Algoritma sangat berguna bagi
seorang insinyur perangkat lunak
dalam memahami ide dasar
pemrograman dan membuat modul
program. Untuk memahami suatu
kalkulasi, seseorang harus memiliki
informasi mendasar tentang sains,
mengingat fakta bahwa kalkulasi pada
dasarnya dibawa ke dunia dari gagasan
rasional numerik.


Di sini yang harus disiapkan adalah kemampuan rasional untuk benarbenar memiliki pilihan untuk mengatur langkah-langkah untuk mengatasi masalah secara tepat. Perhitungan adalah bermacam-macam arah yang dibuat secara gamblang untuk menunjukkan urutan langkah-langkah penanggulangan suatu masalah (berpikir kritis). Secara garis besar, perhitungannya hampir sama dengan strategi yang rutin dilakukan setiap hari, misalnya cara membolakbalikkan mesin kendaraan, menanak nasi, dan lain-lain.

Algoritma adalah berbagai ide yang penting untuk masalah rencana program, khususnya kapasitas PC, masalah dan presisi. Penggunaan ide ini umumnya digunakan dalam rencana perhitungan. Dalam merencanakan suatu perhitungan ada beberapa cara atau teknik, khususnya bermacammacam urutan, artikulasi, tabel panduan, program PC, kode semu dan grafik aliran atau dengan perhitungan kunci. Untuk alasan sains dan pemrograman PC, strategi yang sering digunakan adalah diagram aliran, kode semu, dan perhitungan kunci
Menurut banyak pakar pemrograman

PC bahwa dalam merencanakan suatu perhitungan ada 3 (tiga) bagian yang harus ada, yaitu:

Bagian (masukan). Bagian ini biasanya terdiri dari penentuan faktor, jenis faktor, jenis faktor, konstanta dan batasan (dalam kapasitas).

Bagian (hasil). Bagian ini merupakan tujuan dari perhitungan perencanaan dan proyek. Masalah yang dibahas dalam perhitungan dan proyek harus ditampilkan di bagian hasil. Atribut hasil yang layak adalah masalah benar (balasan) dan penampilan yang ramah (frendly).

Bagian proses (penanganan). Bagian ini merupakan bagian utama dan terpenting dalam merencanakan suatu perhitungan. Pada bagian ini terdapat pemikiran masalah, pemikiran algoritmik (struktur kalimat dan semantik), definisi, strategi (rekursi, korelasi, blending, deduksi dan lainlain).

\section{E. KESIMPULAN}

Pemrograman (menulis program komputer) adalah sebuah gadget yang 
tidak dapat dipegang dan dilihat secara langsung namun dapat dikerjakan dan dirasakan manfaatnya. panduan yang akan mengeksekusi perintah.

$\begin{array}{ccr}\text { Pemrograman } & \text { disebut } & \text { juga } \\ \text { penerjemah } & \text { perintah } & \text { yang } \\ \text { dikendalikan oleh klien } & \text { PC } & \text { untuk }\end{array}$
dikirim atau ditangani oleh peralatan. Melalui pemrograman atau pemrograman PC dapat menjalankan perintah. Dengan begitu pekerjaan manusia akan lebih muda dan praktis dalam melakukan komunikasi atau berinteraksi dengan jarak yang jauh.

Pemrograman memiliki bagianbagian yang bekerja sama untuk membentuk satu kesatuan dalam menyelesaikan kapasitasnya. Bagianbagian ini dipartisi menjadi tiga kelompok, untuk lebih spesifik, Kerangka Kerja, Kerangka Aplikasi dan Dialek Pemrograman.

Kerangka kerja adalah program PC yang berisi perintah yang bertanggung jawab untuk menyelesaikan hubungan antara orang dan PC, sehingga PC dapat diisi sesuai keinginan. Sementara kerangka kerja aplikasi adalah sekumpulan petunjuk unik di PC dalam menyelesaikan tanggung jawab tertentu.
Bahasa program adalah metode untuk menyampaikan dan menghubungkan antara manusia sebagai makhluk hidup dan mesin yang dalam situasi ini adalah PC sebagai gadget memudahkan manusia dalam berkomunikasi dengan jarak yang jauh sekalipun tetap bisa dijangkau, akan tetapi tetap ada batasan di setiap kebijakan yang di berlakukan di tempat yang berbeda beda sesuai ketentuan yang berlaku baik dari sistem elektronik maupun kebijakan pemerintah.

Kerangka kerja data adalah aplikasi PC untuk membantu pelaksanaan afiliasi: proyek, yayasan, dukungan PC, pemrograman, dan data. Kerangka Data Dewan adalah ruang signifikan yang menggarisbawahi organisasi terkait uang dan individu.[4]

\section{DAFTAR PUSTAKA}


[1] 'Yahfizham.' 2019. Dasar-Dasar Komputer. Medan : Perdana Publishing

[2] Roger.2002 Rekayasa Perangkat Lunak. Yogyakarta : Andi.

[3] D. Melwin Syafrizal. 2007. Mengenal Hardware, Software Dan Pengelolaan Instasi Komputer. Yogyakarta : Andi.

[4] B. Sunaryo1 , M. Ilhamdi Rusydi*1, Abdul Manab1 , Amirul Luthfi1 , Rudi1 ,Trisya Septianal Sistem Informasi Manajemen Perangkat Elektronik Berbasis Web

TEKNOSI, Vol. 02, No. 01, April 2016.

[5] Adi Nugroho, 2010, Rekayasa Perangkat Lunak Berbasis Objek dengan Metode

USDP, Andi, Yogyakarta. (2005:10)

18

[6] Jogiyanto, H. M, (1999) Analisis dan Desain Sistem Informasi, Yogyakarta: Andi. Kadir, Abdul, (2008)

[7] Andri, Kristanto. 2007. "Perancangan Sistem Informasi Dan Aplikasinya." Klaten: Gava Media.

[8] Moekijat. 2011. "Sistem Informasi Manajemen \& Definisi Data." Bandung: Remaja Roskadarya.
[9] Optimalisasi Senayan Sebagai Perangkat Lunak Berbasis Open Source untuk Perpustakaan Seni. Magazine : Visi Pustaka, Edition : Vol. 13 No. 1 - April 2011.

[10] Pengenalan Koumputer dan Teknologi Informasi Samsudin, M furqan, M Ikhsan

\section{BIODATA DIRI}

Ahmad Fadhil Hidayat, saat ini sebagai

Mahasiswa aktif program S1 Sistem 21

Informasi, Fakultas Sains dan Teknologi

Univeritas islam Negeri Sumatera Utara Medan. 


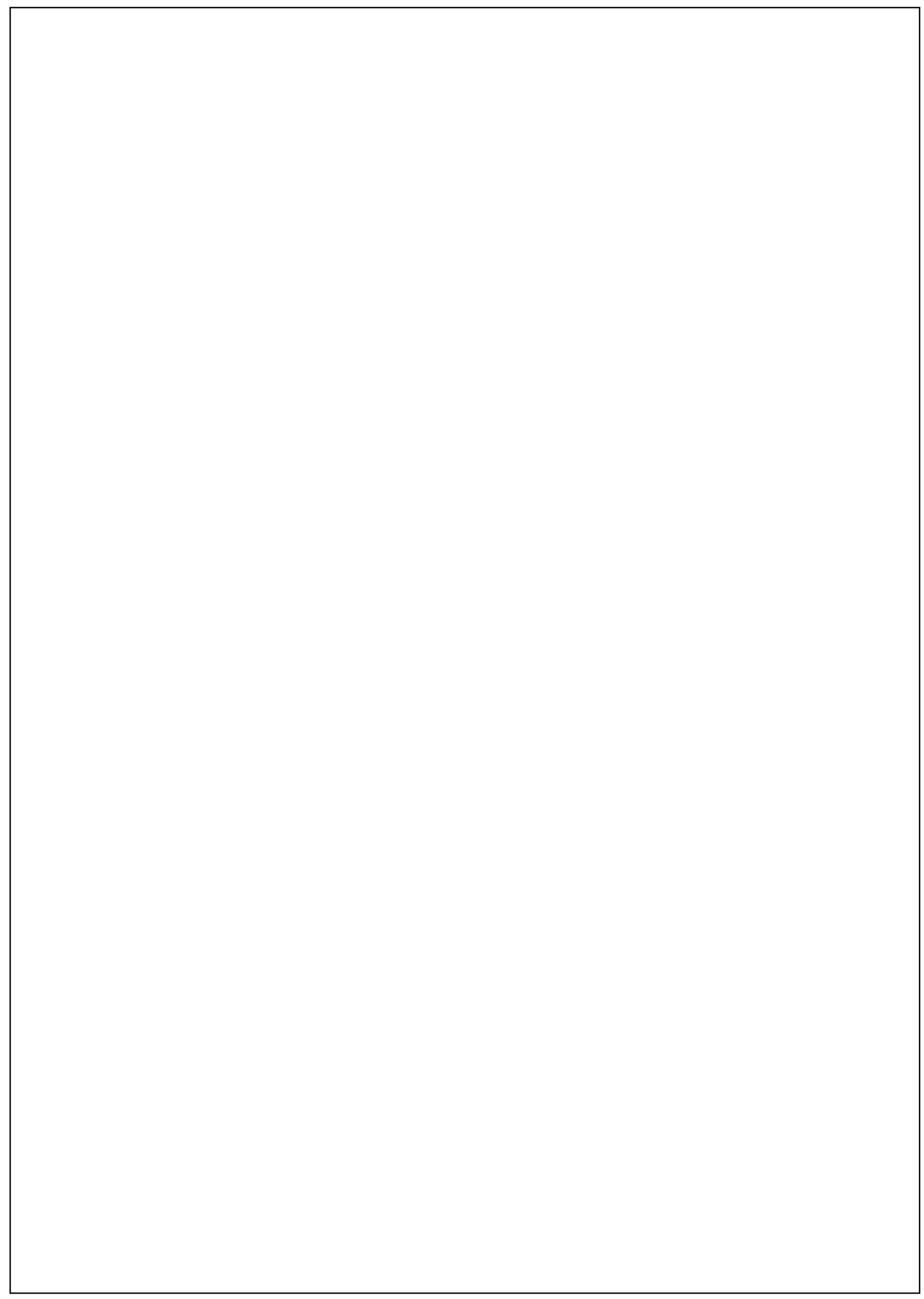




\section{Jurnal_PIK_Ahmad_Fadhil_Hidayat.docx}

ORIGINALITY REPORT

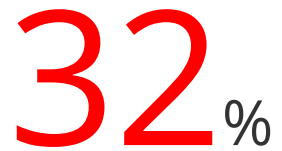

SIMILARITY INDEX
$31 \%$

INTERNET SOURCES
$3 \%$

PUBLICATIONS
$10 \%$

STUDENT PAPERS

PRIMARY SOURCES

1 Www.coursehero.com

Internet Source

2 WwW.researchgate.net

Internet Source

3 123dok.com

4 riskiadongan86.blogspot.com

5 ojs.unikom.ac.id

Internet Source

6 ayoksinau.teknosentrik.com

7 id.berita.yahoo.com 
10 pendidikan.co.id

11 www.perpusnas.go.id

12 wWW.scribd.com

Internet Source

13 Submitted to Universitas Sebelas Maret

14 Submitted to Sriwijaya University

Student Paper

15 Rachman Kurniawan. "REKAYASA PERANGKAT

LUNAK MONITORING DAN PELAPORAN

$<1 \%$

KEBERSIHAN DAN PERTAMANAN KOTA

PALEMBANG DENGAN TEKNOLOGI MOBILE

CROSS PLATFORM", Jurnal Nasional IImu

Komputer, 2020

Publication

16 docplayer.info

17 ejournal.akademitelkom.ac.id

Internet Source 18 repository.usahidsolo.ac.id 
20 invotek.ppj.unp.ac.id

21 jurnal.ar-raniry.ac.id

Internet Source

22 he-wroteyou.com

23 petite-armoire.blogspot.com

24 www.sciencegate.app

Internet Source

25 mustarambhayangkara.blogspot.com

26 roycok.wordpress.com

27 text-id.123dok.com

28 www.pengertianku.net

Internet Source

29 pengajar.co.id 
Exclude bibliography On 